\title{
Evaluation of Viability and Proliferation Profiles on Macrophages Treated with Silica Nanoparticles In Vitro via Plate-Based, Flow Cytometry, and Coulter Counter Assays
}

\author{
S. Bancos, ${ }^{1}$ D.-H. Tsai, ${ }^{2}$ V. Hackley, ${ }^{2}$ J. L. Weaver, ${ }^{1}$ and K. M. Tyner ${ }^{1}$ \\ ${ }^{1}$ Center for Drug Evaluation and Research, U.S. Food and Drug Administration, Building 64, \\ Room 2086 HFD-910, 10903 New Hampshire Avenue, Silver Spring, MD 20993, USA \\ ${ }^{2}$ Material Measurement Laboratory, National Institute of Standards and Technology, 100 Bureau Drive, \\ Mail Stop 8520, Gaithersburg, MD 20899-850, USA \\ Correspondence should be addressed to K. M. Tyner, katherine.tyner@fda.hhs.gov
}

Received 27 June 2012; Accepted 26 August 2012

Academic Editors: F. Grasset, A. Hu, W. Lu, and Y. Zhang

Copyright ( $) 2012$ S. Bancos et al. This is an open access article distributed under the Creative Commons Attribution License, which permits unrestricted use, distribution, and reproduction in any medium, provided the original work is properly cited.

\begin{abstract}
Nanoparticles (NPs) are known to interfere with many high-throughput cell viability and cell proliferation assays, which complicates the assessment of their potential toxic effects. The aim of this study was to compare viability and proliferation results for colloidal silica $\left(\mathrm{SiO}_{2} \mathrm{NP} ; 7 \mathrm{~nm}\right)$ in the RAW 264.7 mouse macrophage cell line using three different techniques: plate-based assays, flow cytometry analysis, and Coulter counter assays. Our data indicate that CellTiter-Blue, XTT, and CyQuant plate-based assays show increased values over control at low $\mathrm{SiO}_{2} \mathrm{NPs}$ concentrations (0.001-0.01 g/L). $\mathrm{SiO}_{2} \mathrm{NPs}$ show little-to-no interference with flow cytometry and Coulter counter assays, which not only were more reliable in determining cell viability and proliferation at low concentrations in vitro, but also identified changes in cell granularity and size that were not captured by the plate-based assays. At high $\mathrm{SiO}_{2} \mathrm{NP}$ concentrations $(1 \mathrm{~g} / \mathrm{L})$ all techniques indicated cytotoxicity. In conclusion, flow cytometry and Coulter counter identified new cellular features, and flow cytometry offered more flexibility in analyzing the viability and proliferation profile of $\mathrm{SiO}_{2}$ NP-treated RAW 264.7 cells.
\end{abstract}

\section{Introduction}

Nanoparticles (NPs) have been proposed as promising tools for therapy, drug delivery, imaging, and active pharmaceutical ingredients [1-5]. An early and crucial stage in drug development is toxicity testing. High throughput in vitro toxicity assays that are widely employed for small molecule drug screening include assays for cell membrane integrity, oxidative stress, apoptosis, proliferation, or metabolic activity [6]. These assays have also been used for NPs toxicity evaluation [7-10]. Although plate-based assays offer several advantages (e.g., fast, easy, and reproducible), accumulating data show that NP interference with plate-based assay substrates can lead to erroneous data and provide little correlation with in vivo studies [11-14]. Some of NP properties that were reported to interfere with viability plate-based assays are surface charge, agglomeration/aggregation, hydrophobicity, and optical or magnetic properties [15-17]. For example, it was reported that titanium dioxide $\mathrm{NPs}\left(\mathrm{TiO}_{2} \mathrm{NP}\right.$; various size and concentrations) bind lactate dehydrogenase (LDH, indicator of cell viability) and alter assay readout [18]; copper NPs (Cu NP, $40 \mathrm{~nm}$ ) and silver NPs (Ag NP, $35 \mathrm{~nm}$ ) inactivate LDH [19]; gold NPs (Au NP; $10 \mathrm{~nm}$ ) can absorb and traffic amine-containing dyes inside cells resulting in false positive results for membrane permeability assays [11]; single-wall carbon nanotubes (SWCNTs) interact with and alter the readout of WST-1 (2-(4-iodophenyl)-3-(4-nitrophenyl)-5(2,4-disulfophenyl)-2H-tetrazolium), Coomasie Blue, Alamar Blue, Neutral Red, MTT, and plate-based cytotoxicity assays [20].

The emerging consensus when using plate-based assays is that NP characterization and their characteristics, choice of cell lines and assays, and the use of appropriate controls are critical in obtaining reliable data $[13,21]$. NP interference 
with viability assays, however, cannot be generalized for all type of NPs, and possible interactions between NPs and assay substrates should be identified for each NP separately. This is a challenging and labor-intensive task resulting in the current toxicology toolbox often being insufficient when applied to NPs. Therefore, it is crucial that alternative methods be developed to test NPs cytotoxicity in vitro. The determination of cell viability using cell dyes coupled with flow cytometry or microscopy techniques offer the advantage of evaluating cell viability on cell-by-cell basis and have been proposed as a method to overcome the plate-based assays interference issues [22].

$\mathrm{SiO}_{2}$ NPs are being proposed as new tools for imaging [23-25] and drug and biologic delivery (e.g., nucleic acidbased reagents and siRNA) [26-30]. $\mathrm{SiO}_{2} \mathrm{NPs}$ may exist in many different forms, including different crystallinity, morphology, and pore structure, with each form exhibiting unique characteristics [31-33]. Although several in vitro studies using $\mathrm{SiO}_{2} \mathrm{NPs}$ have been performed to show either cytotoxicity [34-36] or no effect on viability in vitro [34, 37, 38 ], there is limited information regarding $\mathrm{SiO}_{2}$ NPs interference with plate-based assays. For example, it is known that ViaLight substrate (fluorescent ATP) caused precipitation of $15 \mathrm{~nm} \mathrm{SiO} 2 \mathrm{NP}$ resulting in a cloudy appearance of NP, but without ultimately affecting luminescence signal [22], and $\mathrm{SiO}_{2} \mathrm{NPs}(15 \mathrm{~nm})$ caused precipitation of $\mathrm{LDH}$ resulting in high absorbance values and false-positive results [22]; astrocytes treated with mesoporous silica $\mathrm{NPs}\left(\mathrm{SiO}_{2} \mathrm{NP}\right)$ show decreased MTT signal due to $\mathrm{SiO}_{2}$ NP-mediated formazan exocytosis as opposed to decreased viability [39].

In this study, we compared plate-based, flow cytometry, and Coulter counting assays for their ability to assess the effects of $7 \mathrm{~nm}$ colloidal $\mathrm{SiO}_{2}$ NPs on the RAW 264.7 macrophage cell line. The plate-based assays: CellTiter-Blue, XTT, $\mathrm{LDH}$, and CyQuant were compared with flow cytometry (PI and Calcein AM staining) and Coulter counter assays. Our data show that results obtained by plate-based assays show increased values over control at low $\mathrm{SiO}_{2} \mathrm{NP}$ concentrations. $\mathrm{SiO}_{2}$ NPs show little-to-no interference with flow cytometry and Coulter counter assays, which were not only more reliable in determining cell viability and proliferation in vitro, but also identified additional cellular changes that were not captured by the plate-based assays.

\section{Methods}

2.1. Reagents. $\mathrm{SiO}_{2}$ NPs (7 nm; Ludox, SM-30 colloidal silica) and bacterial lipopolysaccharide were purchased from Sigma. DMEM media was purchased from ATCC; FBS, Penicillin/Streptomycin, PBS, and trypsin were purchased from Invitrogen.

2.2. Determination of NP Concentration. $\mathrm{SiO}_{2}$ NPs were sterile filtered $(0.22 \mu \mathrm{m}$ Millex filter unit) after which thermogravimetric analysis (TGA) was performed as follows: $50 \mu \mathrm{L}$ of $\mathrm{SiO}_{2} \mathrm{NPs}$ were heated to $200^{\circ} \mathrm{C}$ (at a heating rate of $1^{\circ} \mathrm{C} / \mathrm{min}$ ) to remove the bound and unbound water, and the weight concentration was calculated based on starting $\mathrm{SiO}_{2}$
NPs volume. $\mathrm{SiO}_{2}$ NPs stock used for current experiments was between $380 \mathrm{~g} / \mathrm{L}$ and $390 \mathrm{~g} / \mathrm{L}$. This stock concentration was used to prepare dilutions (freshly prepared for each experiment).

2.3. Endotoxin Test. To ensure that $\mathrm{SiO}_{2} \mathrm{NPs}$ are free of Gram-negative bacterial endotoxin contamination, the Limulus amebocyte lysate (LAL) test was performed for all dilutions using LAL QCL-1000 (Lonza, MD, USA), PYROGENT Plus (Lonza, MD, UAS) and Pyrosate (Associates of Cape Code, Inc., MA, USA) kits following the instructions recommended by the manufacturers. All $\mathrm{SiO}_{2} \mathrm{NPs}$ dilutions tested negative for endotoxin in all tests used.

LAL QCL-1000 identifies endotoxin contamination based on a colorimetric method (absorbance 405-410 nm). The kit requires that samples have a $\mathrm{pH}=6-8$. Because $\mathrm{SiO}_{2} \mathrm{NPs}$ have a $\mathrm{pH}=10.25-10.3$, dilutions were performed in $\mathrm{PBS}(\mathrm{pH}=6.5)$. The final $\mathrm{pH}$ values of $\mathrm{SiO}_{2} \mathrm{NPs}$ dilutions in $\mathrm{PBS}\left(\mathrm{pH}=6.5\right.$ ) were between $\mathrm{pH}=6.2$ (for $1 \mathrm{~g} / \mathrm{L} \mathrm{SiO}_{2}$ $\mathrm{NPs}$ ) and $\mathrm{pH}=6.4$ (for $0.001 \mathrm{~g} / \mathrm{L} \mathrm{SiO}_{2} \mathrm{NPs}$ ). Endotoxin values were calculated using an endotoxin standard curve (from E. coli endotoxin O55:B5 with concentrations between $1 \mathrm{EU} / \mathrm{mL}$ and $0.015 \mathrm{EU} / \mathrm{mL}$ ). Standard curve absorbance values were used to calculate the coefficient of correlation $(r=$ $0.902)$, slope $(S=2.86)$, and intercept of mean $\Delta$ absorbance value $(Y=1.375)$. The assay was validated using negative controls (LAL-free water and PBS $\mathrm{pH}=6.5$ ) and positive controls $\left(\mathrm{SiO}_{2} \mathrm{NPs}\right.$ dilutions spiked with $0.5 \mathrm{EU} / \mathrm{mL}$ endotoxin). Water and PBS tested negative for endotoxin whereas all positive controls were endotoxin positive. There was no inhibition noted with this assay.

LAL PYROGENT Plus kit determines gel clot formation in endotoxin-positive samples. $\mathrm{SiO}_{2} \mathrm{NPs}$ were diluted in PBS $\mathrm{pH}=6.5$ (final concentrations: $1 \mathrm{~g} / \mathrm{L}, 0.1 \mathrm{~g} / \mathrm{L}, 0.01 \mathrm{~g} / \mathrm{L}$, and $0.001 \mathrm{~g} / \mathrm{L}$ ) and tested for gel clot formation as recommended by the manufacturer. Negative controls (LAL-free water and PBS) as well as positive controls $\left(\mathrm{SiO}_{2} \mathrm{NPs}\right.$ dilutions spiked with $E$. coli endotoxin $0.5 \mathrm{EU} / \mathrm{mL}$ ) were included. $\mathrm{SiO}_{2} \mathrm{NPs}$ dilutions tested negative for endotoxin. No interference was noted with the assay (all positive control samples formed gel clots). Kit sensitivity is reported as $0.125 \mathrm{EU} / \mathrm{mL}$ endotoxin, which was validated by $E$. coli endotoxin O55:B5 standard controls. Seven standard controls were prepared $(1 \mathrm{EU} / \mathrm{mL}$ to $0.015 \mathrm{EU} / \mathrm{mL}$ ), and the calculated sensitivity was $0.063 \mathrm{EU} /$ $\mathrm{mL}$ (acceptable values are between 0.060 and $0.250 \mathrm{EU} / \mathrm{mL}$ ).

Pyrosate LAL kit forms gel clots in endotoxin-contaminated samples but does not require $\mathrm{pH}$ adjustment. Serial $\mathrm{SiO}_{2}$ NPs dilutions $(1 \mathrm{~g} / \mathrm{L} ; 0.1 \mathrm{~g} / \mathrm{L} ; 0.01 \mathrm{~g} / \mathrm{L}$ and $0.001 \mathrm{~g} / \mathrm{L})$ were prepared in water $\left(\mathrm{SiO}_{2} \mathrm{NPs} \mathrm{pH}=10.25-10.3\right)$. The assay was performed using negative controls (LAL-free water) and positive controls (ready-made endotoxin-spiked sample, provided by the manufacturer). All $\mathrm{SiO}_{2} \mathrm{NPs}$ samples and the negative control were endotoxin free (no gel clot was formed) whereas all positive controls formed gel clots. Pyrosate kit sensitivity is reported as $0.25 \mathrm{EU} / \mathrm{mL}$ endotoxin.

2.4. NP Characterization. $\mathrm{SiO}_{2}$ NPs were analyzed by dynamic light scattering (DLS), transmission electron microscopy 
TABLE 1: Assays used to determine cell viability and proliferation in RAW 264.7 cells exposed to $\mathrm{SiO}_{2} \mathrm{NP}(7 \mathrm{~nm})$ in vitro.

\begin{tabular}{|c|c|c|c|}
\hline Assay & Readout & Instrument & Controls used \\
\hline CellTiter-blue cell viability assay (Promega) & Mitochondrial activity & \multirow{4}{*}{ Plate reader } & \multirow{4}{*}{$\begin{array}{l}\text { Untreated; no cell control; pre- } \\
\text { and postspike controls; positive } \\
\text { control }\end{array}$} \\
\hline In vitro toxicology assay kit XTT based (Sigma) & Mitochondrial activity & & \\
\hline $\begin{array}{l}\text { CytoTox-one homegenouse membrane integrity assay } \\
\text { (Promega) }\end{array}$ & Membrane integrity & & \\
\hline CyQuant NF cell proliferation assay (Invitrogen) & Proliferation & & \\
\hline PI (Invitrogen) & Membrane integrity & \multirow{3}{*}{ Flow cytometer } & \multirow{3}{*}{ Untreated; positive control } \\
\hline Calcein am stain (Invitrogen) & Intracellular esterase activity & & \\
\hline CFSE (Invitrogen) & Proliferation/cell tracking & & \\
\hline Coulter counter & Cell number and size & Coulter counter & Untreated; LPS control \\
\hline
\end{tabular}

(TEM), and electrospray differential mobility analysis (ESDMA). Zeta potential of $\mathrm{SiO}_{2}$ NPs $(38-39 \mathrm{~g} / \mathrm{L}$ in water) was performed on a Malvern Zetasizer instrument (Malvern Instruments, Worcestershire, UK) using disposable capillary cells. Zeta potential for each sample was measured three times at $37^{\circ} \mathrm{C}$; each measurement contained 14 runs. The $\mathrm{pH}$ of $\mathrm{SiO}_{2}$ NPs in water is 10.3 .

DLS was performed on a Malvern Zetasizer instrument (Malvern Instruments, Worcestershire, UK) using UV-disposable cuvettes for low volume (Brand, Germany). $\mathrm{SiO}_{2}$ NPs solutions were analyzed at 10-fold, 100-fold, and 1000 -fold dilutions to probe for concentration-related effects (multiple scatters, agglomeration, and so forth). $\mathrm{SiO}_{2} \mathrm{NPs}$ were measured by DLS in triplicate using water and cell culture media as dispersants. Measurements were performed at $25^{\circ} \mathrm{C}$ (for water dilutions) or $37^{\circ} \mathrm{C}$ (for media dilutions). Each measurement contained 11 runs (10 seconds duration/ run) with 2-minute equilibration time at the beginning of the measurement. Refractive index (RI) and viscosity values were applied for water and media $(\mathrm{RI}=1.334$ for media and 1.330 for water, resp., $0.790 \mathrm{cp}$ viscosity for media and 0.6864 cp viscosity for water).

For TEM analysis an aliquot of $\mathrm{SiO}_{2}$ NPs was dropped onto a holey carbon-coated copper grid (quantifoil, EMS, PA USA) and allowed to air dry. Grids were analyzed on a JEOL $100 \mathrm{CX}$ at $80 \mathrm{kV}$ and $100 \mathrm{kX}$.

The ES-DMA system consists of an electrospray aerosol generator (ES, Model 3480, TSI Inc., MN, USA), a differential mobility analyzer (DMA, Model 3080n, TSI Inc.), and a condensation particle counter (Model 3776, TSI Inc.). Details of the ES-DMA experimental setup have been described in previous publications $[40,41]$. To achieve sufficient resolution and accuracy, samples of colloidal silica were first diluted ( $10^{5}$ fold) with $20 \mathrm{mmol} / \mathrm{L}$ ammonium aqueous solution, $\mathrm{pH}=6.5$. Argon gas was used as sheath flow and the ratio of sheath-to-aerosol flow rates was fixed at a value of 5. Data were collected with a scanning step size of $0.2 \mathrm{~nm}$ for $10 \mathrm{~s}$.

2.5. Cell Culture Conditions. RAW 264.7 mouse macrophagelike cells were purchased from ATCC. All experiments were performed with cells passaged 5-15 times (batch received from ATCC was considered passage 1). Cells were cultured in DMEM media supplemented with FBS (10\%) and Penicillin/Streptomycin $(1 \%)$ at a density of $0.8 \times 10^{4} \mathrm{cells} / \mathrm{cm}^{2}$. This density was determined following vendor recommendation as well as a confirmation titration study (data not shown).

2.6. CellTiter-Blue, XTT, LDH Release, and CyQuant Assays. All methods and assays used in the current communication are summarized in Table 1. RAW 264.7 cells were cultured as described above in 96-well flat bottom plates for 2 days (cells were $\sim 80 \%$ confluent). Media was exchanged for fresh media with or without NPs and cells were cultured for $24 \mathrm{~h}$ after which CellTiter-Blue cell viability assay (Promega), CytoTox-one homogenous membrane integrity assay, in vitro toxicology assay kit XTT-based (Sigma) and CyQuant NF cell proliferation assay (Invitrogen) were applied according to the manufacturer's instructions. In brief, substrates were either added directly to plates or added after the plates were centrifuged ( $400 \mathrm{~g}$ ) and fresh media added to the wells. For CellTiter-Blue and XTT assays, substrates were added at 1:5 ratio; for $\mathrm{LDH}$ release a 1:1 ratio was used. Plates were incubated for $4 \mathrm{~h}$ at $37^{\circ} \mathrm{C}$ (CellTiter-Blue and XTT) or $10 \mathrm{~min}$ at RT (LDH release), after which fluorescence (excitation at $560 \mathrm{~nm}$ and emission at $590 \mathrm{~nm}$ for CellTiter-Blue and LDH release) or absorbance for XTT (450 nm) was measured using a plate reader (Molecular Devices, SpectraMax model). For CyQuant proliferation assays, media was removed, substrate was added, and plates were incubated at $37^{\circ} \mathrm{C}$ for $1 \mathrm{~h}$; fluorescence was measured on a plate reader (excitation at 485 and emission at $530 \mathrm{~nm}$ ). Viability or proliferation in experimental samples was calculated versus nontreated cells. LDH release was calculated versus maximum LDH release (Triton$\mathrm{X}$ treated cells $\pm \mathrm{NP})$. All experiments were run three times in triplicates.

For all plate-based assays, a "no cell" control and pre- and postspike controls were run in parallel. "No cell" controls were setup exactly as described for experimental samples but did not contain cells. Prespike samples were setup exactly as experimental samples but did not contain NPs. After the prespike values were recorded, $\mathrm{SiO}_{2}$ NPs were added and absorbance or fluorescence was immediately measured. These samples were defined as postspike controls. 
TABLE 2: Summary of LAL-base kits used, controls, and results.

\begin{tabular}{|c|c|c|c|c|c|c|c|}
\hline $\begin{array}{l}\mathrm{SiO}_{2} \mathrm{NP} \\
\text { dilutions }\end{array}$ & Kit name & $\begin{array}{l}\text { Endotoxin } \\
\text { sensitivity }\end{array}$ & $\begin{array}{c}\text { E. coli } \\
\text { O55:B55 } \\
\text { standards }\end{array}$ & Positive controls & $\begin{array}{l}\text { Negative } \\
\text { controls }\end{array}$ & Results & Comments \\
\hline $\begin{array}{l}1 \mathrm{~g} / \mathrm{L} ; \\
0.1 \mathrm{~g} / \mathrm{L} ; \\
0.01 \mathrm{~g} / \mathrm{L} \\
0.001 \mathrm{~g} / \mathrm{L}\end{array}$ & LAL QCL-1000 & $\begin{array}{l}\text { A } 405 \mathrm{~nm} \text { is } \\
\text { linear } \\
\text { between } \\
1 \mathrm{EU} / \mathrm{mL} \text { and } \\
0.1 \mathrm{EU} / \mathrm{mL}\end{array}$ & $\begin{array}{c}\text { From } 1 \mathrm{EU} / \mathrm{mL} \\
\text { to } \\
0.015 \mathrm{EU} / \mathrm{mL}\end{array}$ & $\begin{array}{l}\mathrm{SiO}_{2} \mathrm{NP} \text { dilutions } \\
\text { spiked with } \\
\text { E. coli endotoxin } \\
\mathrm{O} 55: \mathrm{B} 55(0.5 \mathrm{EU} / \mathrm{mL})\end{array}$ & $\begin{array}{l}\text { LAL-free } \\
\text { water and PBS }\end{array}$ & $\begin{array}{l}\mathrm{SiO}_{2} \mathrm{NPs} \text { are } \\
\text { endotoxin-free }\end{array}$ & $\begin{array}{c}\text { colorimetric } \\
\text { method; } \mathrm{SiO}_{2} \mathrm{NP} \\
\text { diluted in } \mathrm{PBS} \\
(\mathrm{pH}=6-8)\end{array}$ \\
\hline $\begin{array}{l}1 \mathrm{~g} / \mathrm{L} \\
0.1 \mathrm{~g} / \mathrm{L} ; \\
0.01 \mathrm{~g} / \mathrm{L} \\
0.001 \mathrm{~g} / \mathrm{L} \\
\end{array}$ & PYROGENT Plus & $0.125 \mathrm{EU} / \mathrm{mL}$ & $\begin{array}{c}\text { From } 1 \mathrm{EU} / \mathrm{mL} \\
\text { to } \\
0.015 \mathrm{EU} / \mathrm{mL}\end{array}$ & $\begin{array}{l}\mathrm{SiO}_{2} \mathrm{NP} \text { dilutions } \\
\text { spiked with } \\
\text { E. coli endotoxin } \\
\text { O55:B55 }(0.5 \mathrm{EU} / \mathrm{mL})\end{array}$ & $\begin{array}{l}\text { LAL-free } \\
\text { water and PBS }\end{array}$ & $\begin{array}{l}\mathrm{SiO}_{2} \mathrm{NPs} \text { are } \\
\text { endotoxin-free }\end{array}$ & $\begin{array}{l}\text { gel clot method; } \\
\mathrm{SiO}_{2} \mathrm{NP} \text { diluted in } \\
\text { PBS ( } \mathrm{pH}=6-8)\end{array}$ \\
\hline $\begin{array}{l}1 \mathrm{~g} / \mathrm{L} ; \\
0.1 \mathrm{~g} / \mathrm{L} ; \\
0.01 \mathrm{~g} / \mathrm{L} ; \\
0.001 \mathrm{~g} / \mathrm{L}\end{array}$ & Pyrosate & $0.25 \mathrm{EU} / \mathrm{mL}$ & $\mathrm{N} / \mathrm{A}$ & $\begin{array}{l}\mathrm{SiO}_{2} \mathrm{NP} \text { dilutions } \\
\text { spiked with endotoxin } \\
\text { (provided by vendor) }\end{array}$ & $\begin{array}{l}\text { LAL-free } \\
\text { water }\end{array}$ & $\begin{array}{l}\mathrm{SiO}_{2} \mathrm{NPs} \text { are } \\
\text { endotoxin-free }\end{array}$ & $\begin{array}{l}\text { gel clot method; } \\
\mathrm{SiO}_{2} \mathrm{NP} \text { diluted in } \\
\text { water }(\mathrm{pH}=10.25)\end{array}$ \\
\hline
\end{tabular}

2.7. Propidium Iodide (PI) and Calcein-AM Staining Coupled with Flow Cytometry. RAW 264.7 cells were cultured in 48well plates for 2 days, after which cells were exposed to $\mathrm{SiO}_{2}$ NPs for $24 \mathrm{~h}$. Supernatants were then collected, and cells were detached with trypsin and pooled with corresponding supernatants. Cells were washed in PBS, thoroughly resuspended by pipeting, and stained with PI $(0.05 \mu \mathrm{g} ; 15 \mathrm{~min}$, RT) or calcein green ( $50 \mathrm{nM} 30 \mathrm{~min}, \mathrm{RT})$. Flow analysis was performed on BD FacsAria III using FlowJo and Diva software, respectively. Viability was calculated versus nontreated cells.

\subsection{Proliferation Assays Using Cell Trace CFSE Cell Prolif-} eration Kit (Invitrogen). RAW 264.7 cells were cultured in 48 -well plates for $24 \mathrm{~h}$ at which point cells were stained with CFSE (carboxyfluorescein diacetate, succinimidyl ester; $5 \mu \mathrm{M})$. Fresh media was added, and cells were cultured for another $24 \mathrm{~h}$ at which time cells were exposed to media $\pm \mathrm{SiO}_{2} \mathrm{NPs}$ and incubated for additional $24 \mathrm{~h}$. Supernatant and corresponding trypsin-treated cells were pooled, washed in PBS, and stained with PI. Cell data were collected on a BD FacsAria III, and data was analyzed using FlowJo software. Proliferation is represented in histograms.

\subsection{Cell Size Measurements and Cell Counts Performed Using} Coulter Counter. RAW 264.7 cells are adherent. In order to collect all cells for Coulter counter assays it was imperative to harvest all cells and to make sure that cells were uniformly dispersed (not always achievable with the plate-based trypsin method). Therefore, a cell suspension culture was utilized. In this case, cells were plated in Petri dishes containing Teflon inserts (to prevent cell adhesion) at $1 \times 10^{5}$ cells $/ \mathrm{mL}$ culture media and were exposed to $\mathrm{SiO}_{2} \mathrm{NPs}(0.005 \mathrm{~g} / \mathrm{L}$ or $0.01 \mathrm{~g} / \mathrm{L})$. Dishes were kept on rotating platform $(50 \mathrm{rpm})$ for $24 \mathrm{~h}$ after which cultures were thoroughly resuspended by pipeting. An aliquot was used to determine cell number and size using a Z2 Coulter particles counter and Size analyzer (Beckman Coulter, FL, USA). A 100- $\mu \mathrm{m}$ aperture was used, and cells between $6 \mu \mathrm{m}$ and $35 \mu \mathrm{m}$ were counted.
2.10. Digital Picture Acquisition. RAW 264.7 cells were cultured in 48-well plates for 2 days, after which cells were exposed to $\mathrm{SiO}_{2}$ NPs. At the end of the treatment digital pictures were taken using Scion VisiCapture Image Acquisition software (Scion Corporation, Frederick, MD, USA).

2.11. Statistical Analyses. Statistical analyses were performed using one-way ANOVA followed by Tukey's multiple comparison test (to compare all groups) or two-way ANOVA followed by Bonferroni's multiple comparison test (comparing $\mathrm{SiO}_{2}$ NP-treated samples to control).

\section{Results}

3.1. $\mathrm{SiO}_{2} \mathrm{NPs}$ Characterization. $\mathrm{SiO}_{2} \mathrm{NP}$ size was determined by TEM, ES-DMA, and DLS. Figure 1(a) shows that in dry state the primary size of $\mathrm{SiO}_{2} \mathrm{NP}$ is $\sim 10 \mathrm{~nm}$. ES-DMA data (Figure 1(b)) shows that in solution phase the primary size is $\sim 13 \mathrm{~nm}$ and that $\mathrm{SiO}_{2}$ NPs also form agglomerates $(\sim 18 \mathrm{~nm})$. DLS measurements show that the size of a singlet $\mathrm{SiO}_{2} \mathrm{NP}$ in water (Figure $1(\mathrm{c})$ ) is $\sim 7 \mathrm{~nm}$, and agglomerates form with a size of $\sim 50 \mathrm{~nm}$, which is in agreement with both TEM and ES-DMA results. To evaluate their stability under experimental conditions, $\mathrm{SiO}_{2}$ NPs were diluted in culture media and DLS was performed after $30 \mathrm{~min}, 1 \mathrm{~h}, 3 \mathrm{~h}$, or $24 \mathrm{~h}$ incubation at $37^{\circ} \mathrm{C}$. Figure $1(\mathrm{~d})$ shows that after $30 \mathrm{~min}, 1 \mathrm{~h}$, or $3 \mathrm{~h}$ incubation in media $\mathrm{SiO}_{2}$ NPs exhibit an average size of $\sim 30 \mathrm{~nm}$ (black lines). The DLS distribution of $\mathrm{SiO}_{2} \mathrm{NP}$ in media is not attributable to culture media with FBS since a blank media containing FBS (10\%) was also analyzed by DLS and showed a peak at $\sim 10 \mathrm{~nm}$ and $50 \mathrm{~nm}$ (gray line). After $24 \mathrm{~h}$ incubation $\mathrm{SiO}_{2}$ NPs showed $\sim 100 \mathrm{~nm}$ size (gray dotted line). Zeta potential was also measured, and the recorded values were $-27 \mathrm{mV}$ (measured immediately after dilution in water).

$\mathrm{SiO}_{2}$ NPs were tested for endotoxin contamination by LAL assays, and $\mathrm{SiO}_{2}$ NPs tested negative as described in Material and Methods and as is represented in Table 2. 


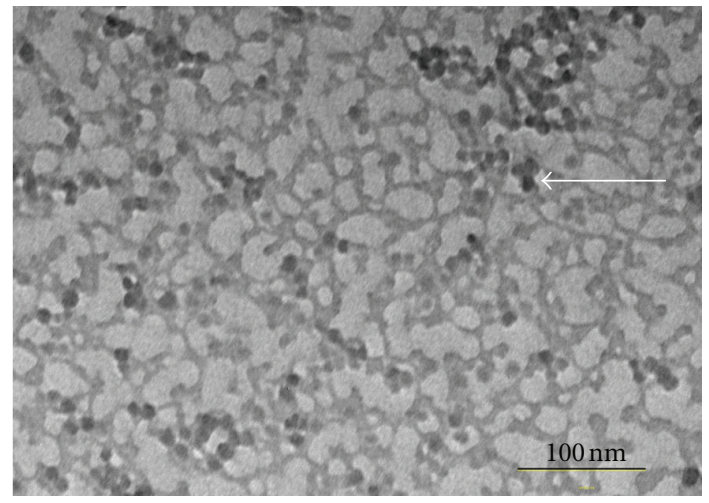

(a) TEM

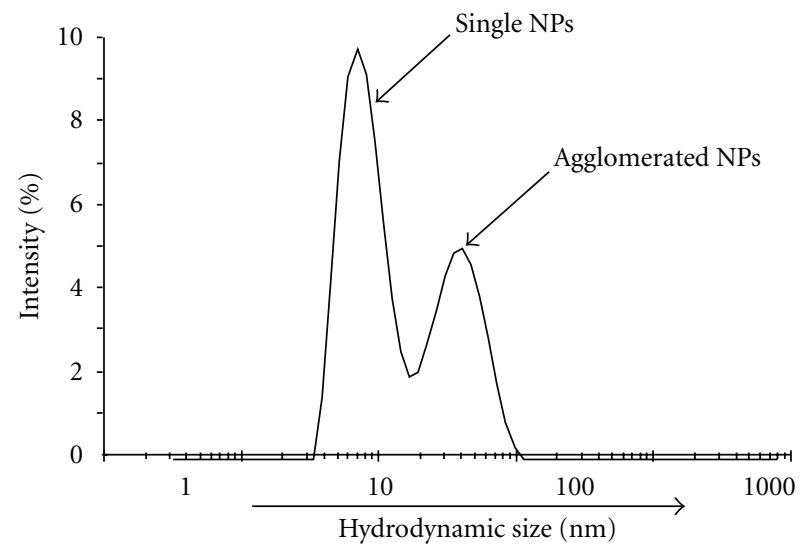

(c) $\mathrm{SiO}_{2} \mathrm{NPs}$ in water

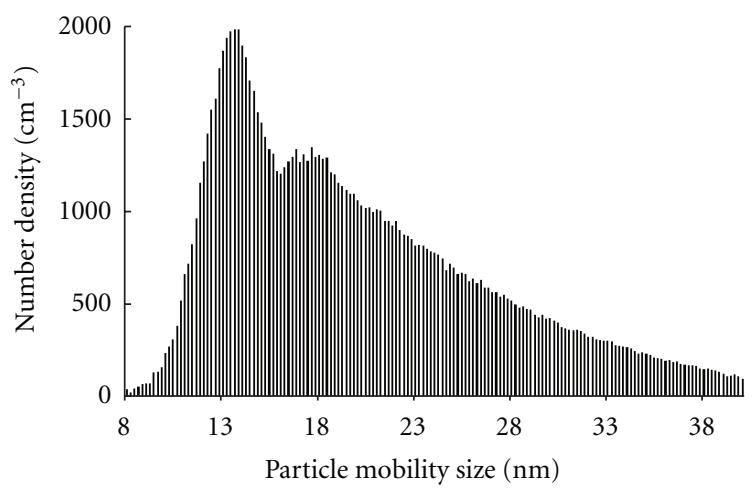

(b) ES-DMA

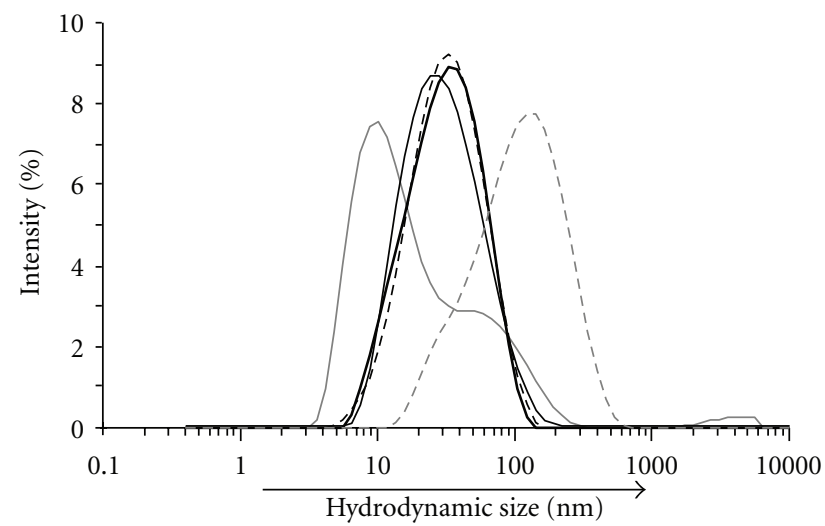

(d) $\mathrm{SiO}_{2}$ NPs in culture media

Figure 1: Characterization of $\mathrm{SiO}_{2} \mathrm{NP}$ size and stability. (a) Representative transmission electron micrograph of $\mathrm{SiO}_{2} \mathrm{NP}$. Arrow points

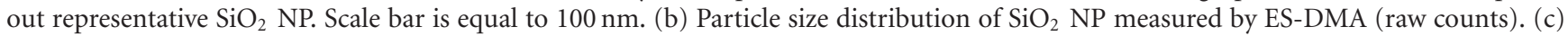
$\mathrm{SiO}_{2} \mathrm{NPs}$ were diluted in water $(38 \mathrm{~g} / \mathrm{L}-39 \mathrm{~g} / \mathrm{L})$ and characterized by DLS. $\mathrm{SiO}_{2} \mathrm{NP}$ display an average size of $\sim 7 \mathrm{~nm}$ in water with some

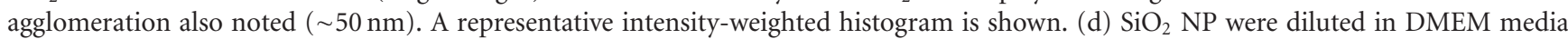
supplemented with FBS and penicillin/streptomycin, incubated at $37^{\circ} \mathrm{C}$ for 30 minutes (black thin line), 60 minutes (black thin punctuated line), $3 \mathrm{~h}$ (black thick line), or $24 \mathrm{~h}$ (gray punctuated line), and 3 measurements were run at each time point. Media only (gray thick line) is also included. One representative intensity-weighted histogram is shown at each time point. $\mathrm{SiO}_{2} \mathrm{NP}$ average diameter is $20 \mathrm{~nm}$ at 30 min and $60 \mathrm{~min}$ and increases to $\sim 60 \mathrm{~nm}$ at $3 \mathrm{~h}$.

\subsection{Evaluation of Viability Profiles of $\mathrm{SiO}_{2} \quad \mathrm{NPs}$-Treated} RAW264.7 Cells by Plate-Based and Flow Cytometry Assays. In order to determine the effect of $\mathrm{SiO}_{2} \mathrm{NPs}$ on macrophage viability in vitro, the membrane permeability and mitochondrial activity of $\mathrm{SiO}_{2}$ NP-treated RAW 264.7 cells were determined by plate-based assays and flow cytometry. CellTiterBlue is a fluorescent method that indicates mitochondrial activity based on the reduction of resazurin to resorufin in metabolically active cells. XTT substrate is reduced to formazan by mitochondrial dehydrogenase in viable cells and can be measured by absorbance. Lactate dehydrogenase (LDH) assay is a fluorometric method and measures $\mathrm{LDH}$ released by cells with damaged membrane into culture media. PI penetrates the leaky membrane of dead/dying cells, binds to their DNA, and it is widely used in membrane integrity and flow cytometry assays. Finally, calcein-AM is a cell-permeant dye that is converted in live cells by esterase activity to the fluorescent calcein green.

In order to detect possible interference with plate-based assays, two experimental setups were utilized. In the first setup, assay substrates were added to the experimental samples as recommended by vendors, and viability was calculated versus untreated samples (Figure 2(a)). In the alternative setup (Figure 2(b)) plates were first centrifuged, and media containing $\mathrm{SiO}_{2}$ NPs removed and replaced with fresh media to which substrates were added. In case of LDH release assays, where cell culture media is used as an endpoint, culture plates were centrifuged, and supernatant was transferred to new plates to which the assay substrate was added. Furthermore, background values obtained from the "no cell" controls were also subtracted (Figure 2(b)). For comparison, the flow cytometry data of PI and calcein green staining is included in both figures.

Figure 2(a) (assays performed as recommended by the vendors) shows that both CellTiter-Blue and XTT assays resulted in values over control at low $\mathrm{SiO}_{2}$ NPs concentrations, and in some cases the increase in viability endpoints is significantly above the control cells (CellTiter-Blue and XTT assays at $0.001 \mathrm{~g} / \mathrm{L}$ or $\left.0.01 \mathrm{~g} / \mathrm{L} \mathrm{SiO}_{2} \mathrm{NPs}\right)$. However, LDHrelease, PI and calcein AM staining showed a decrease in cell 


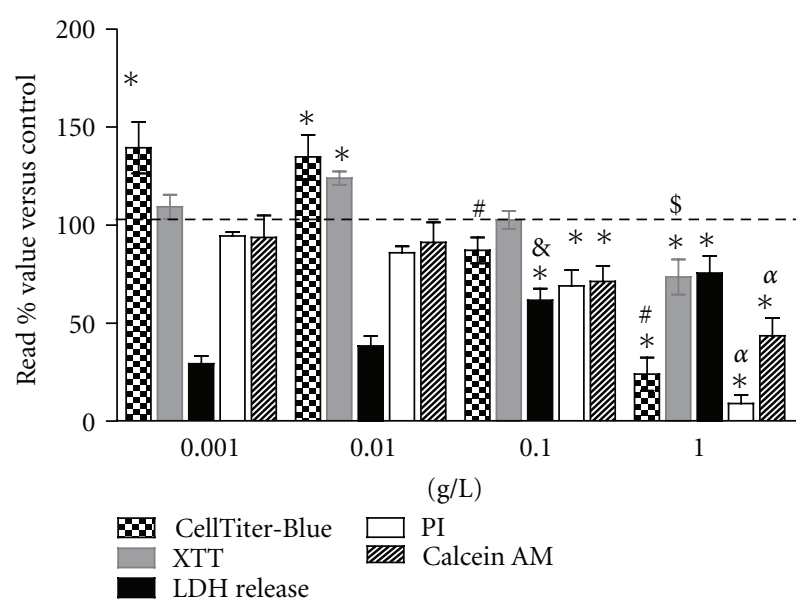

(a)

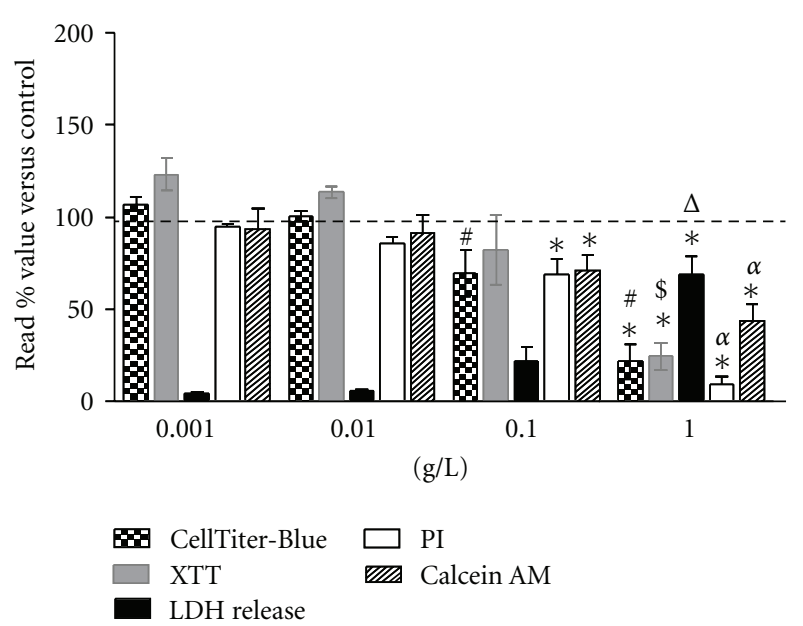

(b)

FIGURE 2: $\mathrm{SiO}_{2}$ NP effect on cell viability determined by plate-based and flow cytometry assays. RAW 264.7 mouse macrophage-like cells were cultured in DMEM-supplemented media for $48 \mathrm{~h}$ after which cells were exposed to $\mathrm{SiO}_{2} \mathrm{NP}$ for $24 \mathrm{~h}$, and viability was evaluated by plate-based assays (CellTiter-Blue, XTT, and LDH) and flow cytometry (PI staining and Calcein AM). (a) CellTiter-Blue and XTT assays determined increased values over control at low $\mathrm{SiO}_{2} \mathrm{NP}$ concentrations. LDH-release, PI, Calcein AM, and LDH-release staining follow a concentration-dependent pattern with significant change at $0.1 \mathrm{~g} / \mathrm{L}$ and $1 \mathrm{~g} / \mathrm{L} \mathrm{SiO}{ }_{2} \mathrm{NPs}$, respectively. (b) CellTiter-Blue, PI, and Calcein AM staining show significant decrease in mitochondrial activity and viability, respectively, at $0.1 \mathrm{~g} / \mathrm{L}$ and $1 \mathrm{~g} / \mathrm{L} \mathrm{SiO}_{2} \mathrm{NPs}_{\mathrm{shereas}} \mathrm{XTT}$ and LDH show significant change only at $1 \mathrm{~g} / \mathrm{L} \mathrm{SiO}_{2}$ NPs. Bars show average and SEM of 5-9 samples from independent experiments. Statistical analysis was performed using one-way ANOVA followed by Tukey's multiple comparison test, and $*(P<0.05)$ shows statistical significant difference versus control. ${ }^{\#} P<0.05$ shows statistical significant difference in $0.1 \mathrm{~g} / \mathrm{L}$ versus $0.01 \mathrm{~g} / \mathrm{L}$ and $1 \mathrm{~g} / \mathrm{L}$ versus $0.1 \mathrm{~g} / \mathrm{L}$, respectively, (CellTiter-Blue); ${ }^{\$} P<0.05$ shows statistical significant difference in $1 \mathrm{~g} / \mathrm{L}$ versus $0.1 \mathrm{~g} / \mathrm{L}(\mathrm{XTT}) ;{ }^{\&} P<0.05$ shows statistical significant difference in $0.1 \mathrm{~g} / \mathrm{L}$ versus $0.01 \mathrm{~g} / \mathrm{L}(\mathrm{LDH}) ;{ }^{\Delta} P<0.05$ shows statistical significant difference in $1 \mathrm{~g} / \mathrm{L}$ versus $0.1 \mathrm{~g} / \mathrm{L}$ (LDH release); ${ }^{\alpha} P<0.05$ shows statistical significant difference in $1 \mathrm{~g} / \mathrm{L}$ versus $0.1 \mathrm{~g} / \mathrm{L}$ (PI and Calcein AM, resp.). Dashed line at 100 represents control cells viability.

viability with significant changes at $0.1 \mathrm{~g} / \mathrm{L}$ and $1 \mathrm{~g} / \mathrm{L} \mathrm{SiO} 2$ NPs. All assays showed significant decrease in cell viability endpoints at $1 \mathrm{~g} / \mathrm{L} \mathrm{SiO} 2$ NPs.

In Figure 2(b), where plates were centrifuged prior to substrate addition and background values were subtracted, values in CellTiter-Blue, XTT and LDH-release assays were reduced although significant decrease in cell viability compared to the control was still only detected at $1 \mathrm{~g} / \mathrm{L} \mathrm{SiO}_{2} \mathrm{NPs}$. Note that in Figure 2(a) LDH release reached $\sim 62 \%$ at $0.1 \mathrm{~g} / \mathrm{L}$ $\mathrm{SiO} 2$ NPs whereas in Figure 2(b) at the same concentration $\mathrm{LDH}-$ release value was $\sim 22 \%$. Flow cytometry assays (PI and calcein staining) were more sensitive in detecting altered cell activity, with change detected starting at $0.1 \mathrm{~g} / \mathrm{L}$.

In order to detect possible interference of $\mathrm{SiO}_{2} \mathrm{NPs}$ with plate-based assays, a series of pre- and postspike controls were utilized for plate-based assays (as described in Material and Methods). No significant difference in measured values between pre and postspike samples was observed (see Supplementary material available online at doi:10.5402/2012/ 454072).

3.3. Flow Cytometry and Visual Observations Identified Morphological Modifications in $\mathrm{SiO}_{2} \mathrm{NPs}$-Treated RAW 264.7 Cells In Vitro. While assessing the effect of $\mathrm{SiO}_{2} \mathrm{NPs}$ on cell viability by flow cytometry, it was observed that $\mathrm{SiO}_{2} \mathrm{NP}-$ treated RAW 264.7 cells show modification in their side scatter (SSC), which is a measure of relative cell granularity. In
Figure 3(a) flow cytometry data are represented as plots. For visualization purposes and in order to quantify the changes in cell granularity each histogram is divided into quadrants (From Q1 to Q4). Quadrants coordinates were chosen based on cell distribution in no treatment samples so that the main population is found in one quadrant (Q4). Figure 3 (a) shows that there was a wider distribution of cells on the SSC axis (indicative of increased relative granularity) in $\mathrm{SiO}_{2}$ NP- and LPS-treated cells versus control. Table 3 shows a quantitative analysis of cell distribution in each quadrant, and it illustrates that in $\mathrm{SiO}_{2} \mathrm{NP}$-treated cells $\sim 28 \%$ exhibit increased granularity versus $\sim 13 \%$ in no treatment cells. In LPS-treated cells $\sim 42 \%$ of cells showed changes in SSC.

Morphological changes were observed by visual inspection of cell cultures. Figure 3(b) shows that $\mathrm{SiO}_{2} \mathrm{NPs}$-treated cells show increased cell size (black arrows) at $0.001 \mathrm{~g} / \mathrm{L}$ and $0.01 \mathrm{~g} / \mathrm{L} \mathrm{SiO}_{2} \quad \mathrm{NPs}$. Higher concentration $(0.1 \mathrm{~g} / \mathrm{L})$ caused enlarged cells and also caused significant cell death (indicated by cell debris formation, black punctuated arrow). $\mathrm{SiO}_{2} \mathrm{NPs}$ $(1 \mathrm{~g} / \mathrm{L})$ killed most of the cells and precipitated in culture dishes (white arrow). Similarly to flow cytometry data LPStreated cells appeared more granular than control samples; however, the morphology of LPS-treated cells differed from $\mathrm{SiO} 2 \mathrm{NP}$-treated cells, as visible in Figure 3(b).

In order to obtain an exact cell size, Coulter counter measurements were performed. RAW 264.7 cells were cultured in the presence of $\mathrm{SiO}_{2} \mathrm{NPs}(0.005 \mathrm{~g} / \mathrm{L}$ or $0.01 \mathrm{~g} / \mathrm{L})$ or 

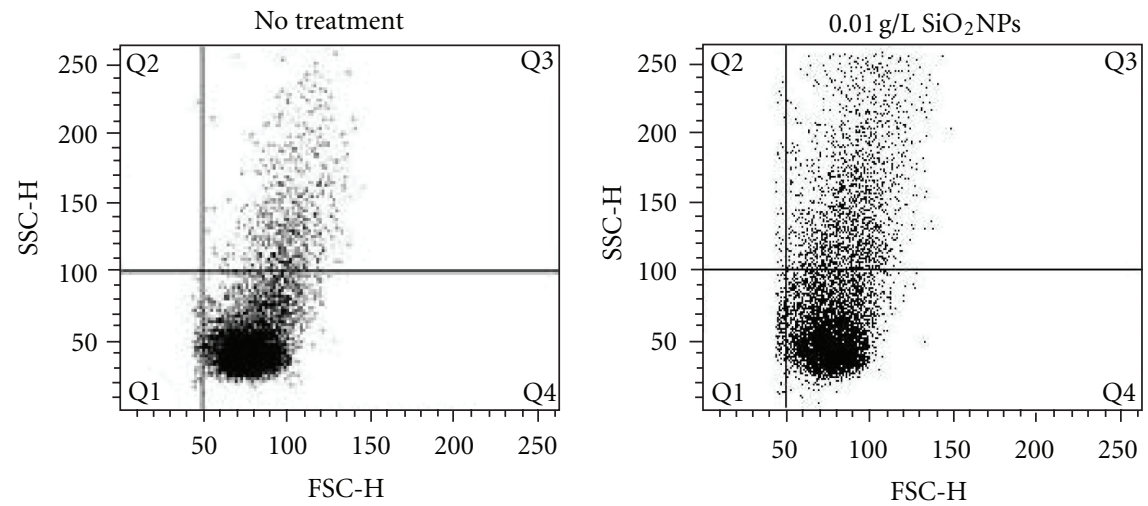

(a)
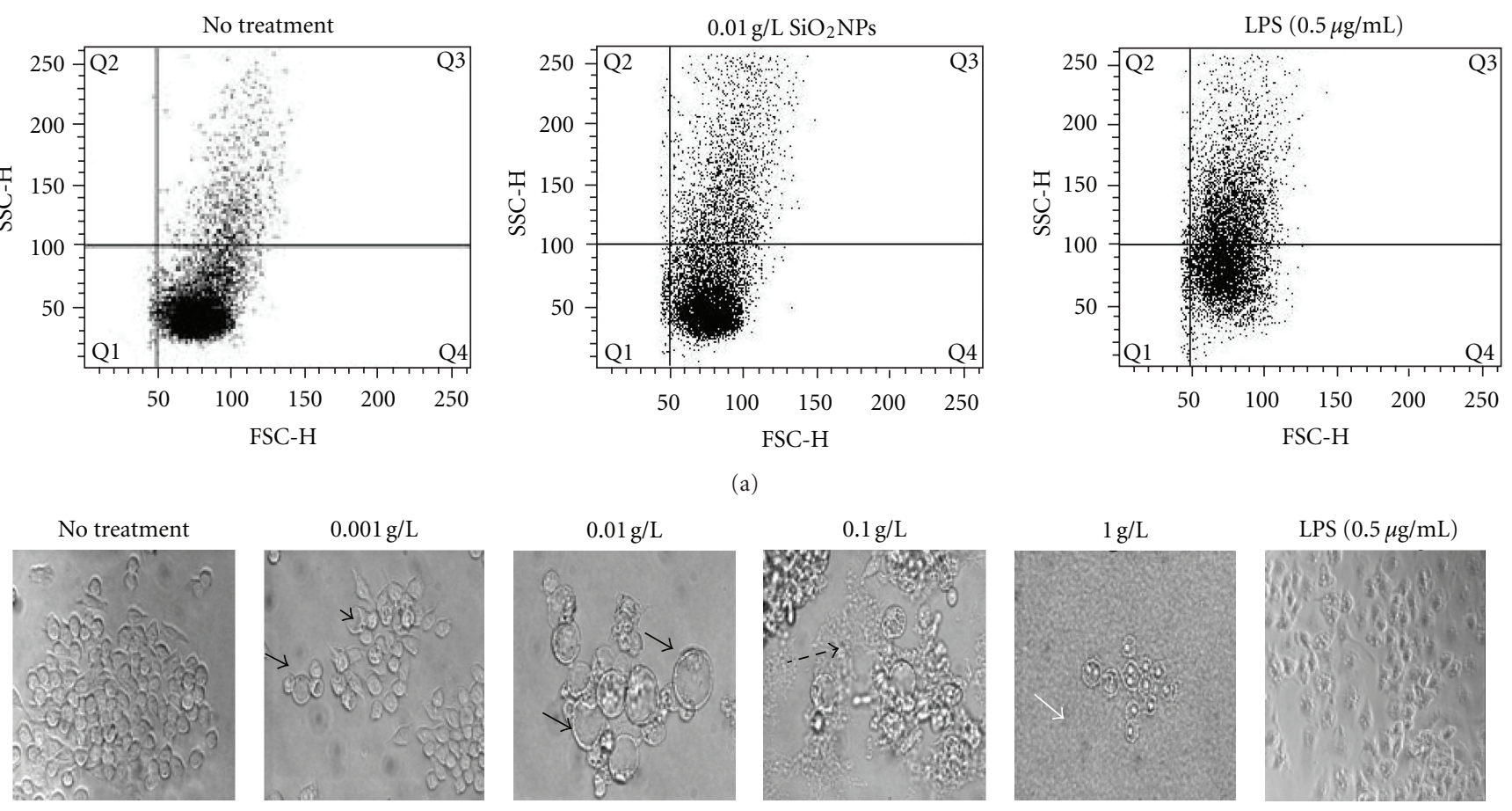

(b)

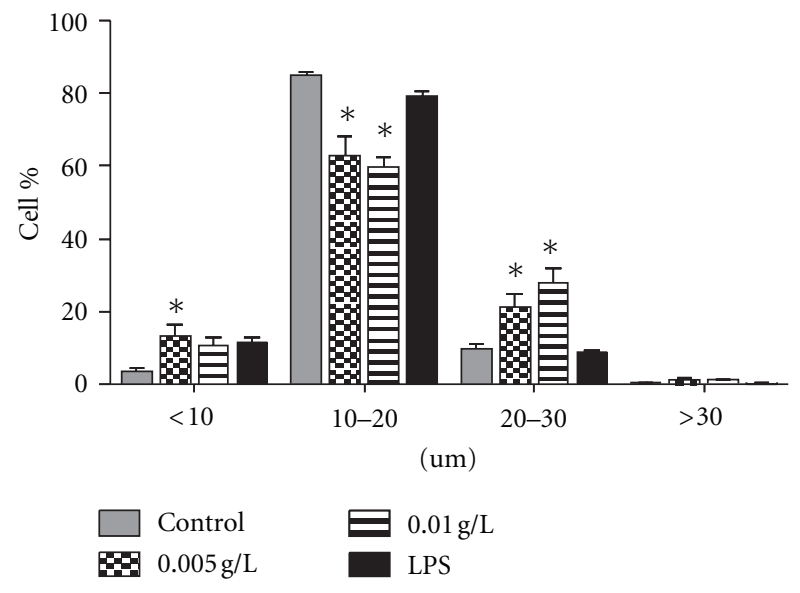

(c)

Figure 3: $\mathrm{SiO}_{2}$ NPs cause cell morphology changes in mouse macrophages. (a) Flow cytometry analysis revealed changes in granularity (SSC) in $\mathrm{SiO}_{2} \mathrm{NP}$-and LPS-treated cells. LPS $(0.5 \mu \mathrm{g} / \mathrm{mL})$ was used as a positive control. Data are represented as histograms each divided in quadrants (Q1 to Q4). Average values of cell percentages $( \pm \mathrm{SEM} ; N=6)$ are also shown in Table 3. Statistical analysis was performed using two-way ANOVA followed by Bonferroni test. ${ }^{*} P<0.01$ shows statistical difference when compared to corresponding control population. (b) Digital pictures of RAW cells in culture were taken at $24 \mathrm{~h}(20 \mathrm{x})$. Lower concentration of $\mathrm{SiO}_{2} \mathrm{NP}(0.001-0.01 \mathrm{~g} / \mathrm{L})$ produced increases in cell size (black arrows) whereas high concentration of $\mathrm{SiO}_{2} \mathrm{NP}(0.1 \mathrm{~g} / \mathrm{L}$ and $1 \mathrm{~g} / \mathrm{L}$ ) caused cell debris formation and cell death (punctuated black arrow). $\mathrm{SiO}_{2} \mathrm{NPs}$ form agglomerates and precipitate at high concentrations ( $1 \mathrm{~g} / \mathrm{L}$; white arrow). (c) Cell size of control and $\mathrm{SiO}_{2} \mathrm{NP}_{\text {-treated }}$ cells were measured by Coulter counter assay. There is a change in size distribution in $\mathrm{SiO}_{2} \mathrm{NP}$-treated RAW 264.7 cells. Bars show the average of and SEM of 6 samples from independent experiments. ${ }^{*} P<0.05$ is considered statistical significant as determined by two-way ANOVA followed by Bonferroni's multiple comparison test (comparing $\mathrm{SiO}_{2}$ NP-treated samples to control).

LPS in cell suspension for $24 \mathrm{~h}$. As Figure 3(c) shows, $\sim 85 \%$ of untreated cells exhibited sizes between $10-20 \mu \mathrm{m}$. LPStreated cells showed similar cell size distribution to control cells. However, $\mathrm{SiO}_{2}$ NPs-treated cells showed a decrease in 10 and $20 \mu \mathrm{m}$ cells but showed a significant increase in cells between 20 and $30 \mu \mathrm{m}$.
3.4. $\mathrm{SiO}_{2} \mathrm{NPs}$ Determine Increased Proliferation (Plate-Based Assays) but Show Decreased Proliferation (Coulter Counter and Flow Cytometry Assays). In order to determine if $\mathrm{SiO}_{2}$ NPs influence cell proliferation, $\mathrm{SiO}_{2} \mathrm{NP}$-treated RAW 264.7 cells were assayed for cell proliferation using 3 different methods: plate-based assays, Coulter counter, and flow cytometry. 


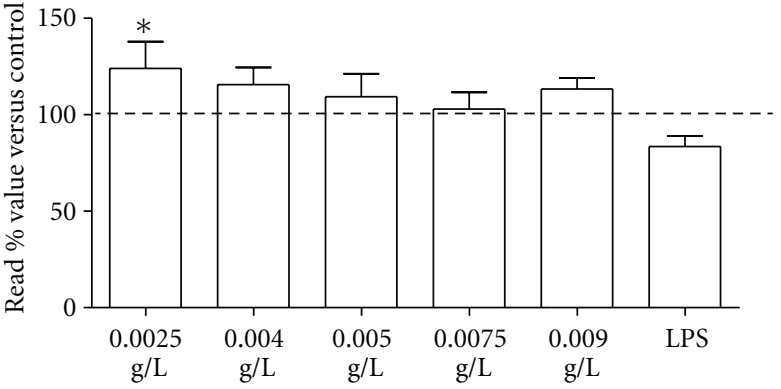

(a) CyQuant proliferation assay

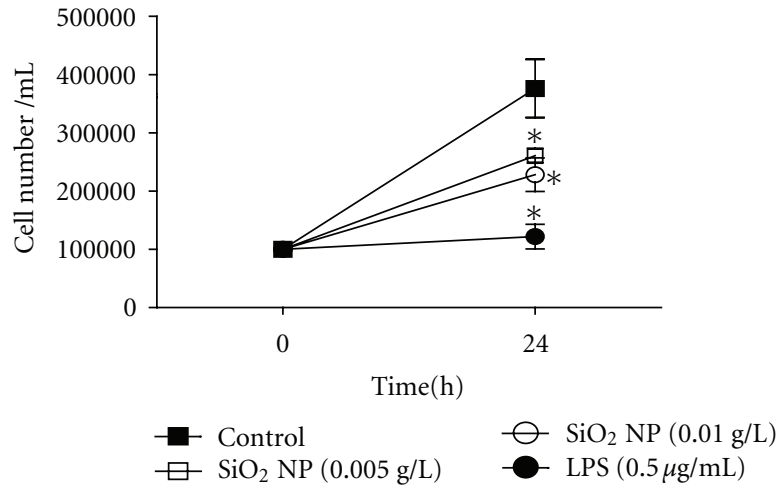

(b) Coulter counter assay

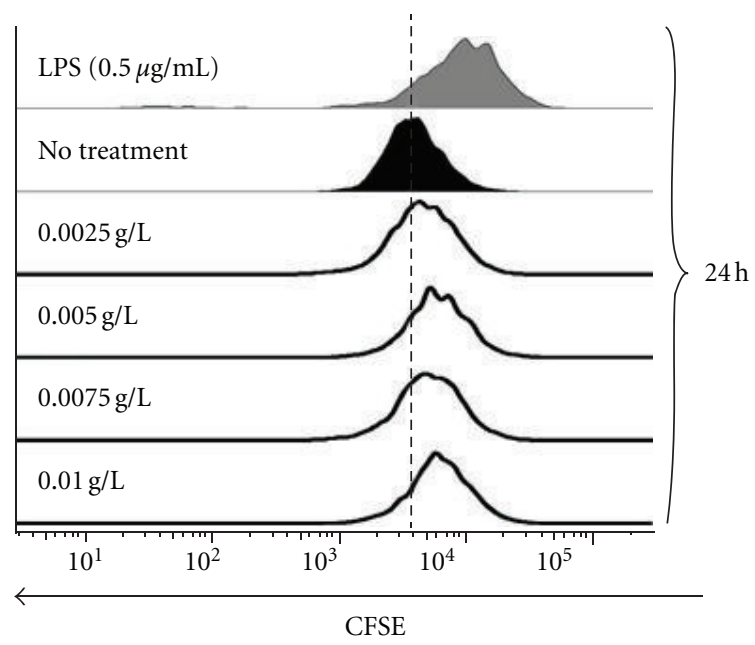

(c) CFSE assay

FIGURE 4: Proliferation assays show contradictory results among methods. RAW 264.7 cells were plated in DMEM-supplemented media, and cells were processed differently dependent on the assay (as described in Section 2). (a) There is an increased proliferation in cells treated with $\mathrm{g} / \mathrm{L} \mathrm{SiO}_{2} \mathrm{NP}$; punctuated line shows control value (100\%). (b) There is a decrease in cell number in cells exposed to $\mathrm{SiO} \mathrm{NP}_{2}(0.005 \mathrm{~g} / \mathrm{L}$ and $0.01 \mathrm{~g} / \mathrm{L}$ ) and LPS at $24 \mathrm{~h}$. (c) CFSE staining shows a nonsignificant delay in cell proliferation. Punctuated line shows the peak in CFSE intensity in control sample. High CFSE intensity (as shown in CFSE-stained cells on day 1 and CFSE-stained cells cultured with no FBS) indicates reduced cell proliferation. Experiment was performed 3 times, and one representative histogram is shown. (a) and (b) show average with SEM $(N=6$ in (a) and $N=8$ samples in (b)) from different experiments. Statistical analysis was performed using one-way ANOVA followed by Tukey's posttest, and ${ }^{*} P<0.05$ is considered significant when comparing $\mathrm{SiO}_{2}$ NPs-treated cells to control.

TABLe 3

\begin{tabular}{lccc}
\hline & Control & $0.01 \mathrm{~g} / \mathrm{L}$ & LPS $(0.5 \mu \mathrm{g} / \mathrm{mL})$ \\
\hline $\mathrm{Q}_{1}$ & $3.9 \pm 1.14$ & $8.06 \pm 2.14$ & $5.6 \pm 1.84$ \\
$\mathrm{Q}_{2}$ & $2.17 \pm 2.05$ & $0.85 \pm 0.12$ & $1.17 \pm 0.20$ \\
$\mathrm{Q}_{3}$ & $12.56 \pm 1.54$ & $28.65 \pm 1.9^{*}$ & $42.15 \pm 1.40^{*}$ \\
$\mathrm{Q}_{4}$ & $83 \pm 2.22$ & $62.7 \pm 4.17^{*}$ & $51.06 \pm 3.25^{*}$ \\
\hline
\end{tabular}

RAW 264.7 cells were exposed to $\mathrm{SiO}_{2}$ NPs $(0.0025 \mathrm{~g} / \mathrm{L}-$ $0.009 \mathrm{~g} / \mathrm{L}$ ) for $24 \mathrm{~h}$, and proliferation was determined by CyQuant 96 plate-based assay (measuring DNA content via fluorescence). Figure 4(a) shows that the plate-based assay shows increased values over control when treated with $\mathrm{SiO}_{2}$ NPs $(0.0025 \mathrm{~g} / \mathrm{L})$. Pre- and postspike controls were also included, and controls did not indicate assay interference (data not shown).
Cells were also counted using Coulter counter assays, and 2 concentrations were used: $0.005 \mathrm{~g} / \mathrm{L}$ and $0.01 \mathrm{~g} / \mathrm{L} \mathrm{SiO}_{2} \mathrm{NP}$. LPS was used as positive control. Figure 4(b) shows that $\mathrm{SiO}_{2}$ NPs cause a concentration-dependent decrease in RAW 264.7 cell numbers. There was $\sim 30 \%$ decrease in cell number at $0.005 \mathrm{~g} / \mathrm{L}$ and $\sim 40 \%$ decrease at $0.01 \mathrm{~g} / \mathrm{L}$. However, based on PI data (Figure 2(b)) $0.01 \mathrm{~g} / \mathrm{L} \mathrm{SiO}_{2} \mathrm{NP}$ causes $\sim 20 \%$ decrease in viability. To make sure that the decrease in cell number is not partly due to decrease in viability, flow cytometry measurements using CFSE staining and PI staining were employed which allows analysis of live cell proliferation (by excluding dead, PI-positive cells). CFSE profiles (gated only on live cells) show a decreased proliferation in cells treated with LPS and $\mathrm{SiO}_{2}$ NPs $(0.0025 \mathrm{~g} / \mathrm{L}-0.01 \mathrm{~g} / \mathrm{L}$; Figure $4(\mathrm{c}))$. Although decrease in CFSE intensity occurred in LPS and $\mathrm{SiO}_{2}$ NP-treated samples, these changes were not statistically significant compared to control cells (based on mean fluorescence intensity values, data not shown). 


\section{Discussion}

Plate-based assays are frequently performed for cytotoxicity evaluation, even though NP interference with this type of assay is rampant for many NP constructs. In order to account for NP interference, it is imperative to include controls in the experimental design. Controls can help detect, and in some cases account for, NP interference. Even when all the recommended controls are included, however, there are cases where $\mathrm{NP}$ interference detection and assay result interpretation is problematic $[11,42]$.

"No cell" controls are useful to detect NPs catalyzing assay substrates as well as to provide a background value for the NP solutions; however, the disadvantage of this type of control is that they do not contain cells and therefore NP characteristics (such as formation of protein corona and subsequent interaction with cells), and NP "stickiness" might be different in no-cell controls compared to treated samples. Prespike and postspike controls are recommended and widely used to determine quenching and other effects. However, the incubation time of NP with the substrate in postspiking controls is usually shorter (due to assay stability) and NP characteristics (agglomeration and protein corona) are therefore different, which might not allow complex substrate-NP interactions. In order to remove $\mathrm{SiO}_{2} \mathrm{NP}$ and avoid possible interference with assay substrates, cell cultures were centrifuged, and $\mathrm{SiO}_{2} \mathrm{NP}$-containing media was replaced by fresh media at the end of treatments in Figure 2(b). In the case of CellTiter-Blue and XTT there was an increase value over control at low $\mathrm{SiO}_{2} \mathrm{NP}$ concentrations. These values were decreased when plates were spun down and background values were subtracted. "No cell" controls as well as pre- and postspiked controls did not indicate any significant interference issues. It is possible, therefore, that the increased values over control at low $\mathrm{SiO}_{2} \mathrm{NPs}$ concentrations could be due to increased mitochondrial activity.

Changes in mitochondrial activity are detected by MTT (3-(4, 5-dimethylthiazol-2-yl)-2, 5-diphenyltetrazolium bromide), XTT (2, 3-bis [2-methoxy-4-nitro-5-sulfophenyl]2H-tetrazolium-5-carboxanilide), Alamar blue, resazurin (CellTiter-Blue), and ATP assays, to name only a few. Although, all the abovementioned assays are often termed "viability assays," it is important to understand what the assays are actually measuring and caution should be taken when interpreting assay results. For example, increased values in CellTiter-Blue, XTT, MTT, or other assays might indicate NP assay interference but could also indicate increased mitochondrial activity. For example, the polyphenolic flavonoid genistein caused decreased cell number and cellcycle arrest of human breast cancer cells but let to an increase in MTT values due to increased mitochondrial number and activity [43]. STI571 (Gleevec) caused apoptosis and decrease in cell number in human breast cells but showed increased MTT values due to STI571-mediated inhibition of Abl kinases required for formazan reduction [44]. Therefore, it is highly recommended that cytotoxicity evaluation should comprise of multiple tests and endpoints in order to determine the true effect of the NP on the cells. Current studies are underway to determine if our observed MTT increase is due to NP assay interference, or an actual increase in mitochondrial activity.

Similar to mitochondrial assays, cell proliferation should be evaluated by complementary methods. For example, in this study Coulter counter measurement was the most sensitive technique in determining a significant decrease in cell number in $\mathrm{SiO}_{2}$ NP-treated cells versus control. On the other hand, the plate-based CyQuant assay showed an increase of cell proliferation (at $0.0025 \mathrm{~g} / \mathrm{L}$ ), with no other significant change noted. CFSE only showed a trend of decreased proliferation (complementing the Coulter counter assay).

Protocol modifications can influence assay outcomes therefore any adjustments when performing plate-based assays should be recorded and reported. Changes such as plate centrifugation and supernatant transfer as well as background subtraction lead to decreased values in CellTiterBlue, XTT, and LDH-release assays. For example, LDHrelease showed significant decrease in membrane integrity at $0.1 \mathrm{~g} / \mathrm{L} \mathrm{SiO}{ }_{2} \mathrm{NP}$, but when the plates were centrifuged the only significant decrease in membrane integrity occurred at $1 \mathrm{~g} / \mathrm{L}$. It is possible that similar to $\mathrm{TiO}_{2} \mathrm{NP}$ [18], $\mathrm{SiO}_{2} \mathrm{NPs}$ bind $\mathrm{LDH}$, and $\mathrm{SiO}_{2} \mathrm{NP}-\mathrm{LDH}$ complexes were removed after plate centrifugation (in Figure 2(b)). Both PI and LDH release are indicators of membrane integrity; therefore, it was expected that LDH release will correlate with PI staining results. However, this was the case only in Figure 2(a) but not in Figure 2(b). Therefore, when complementary assays result in contradictory data, they should be confirmed by a third technique or assay.

Although sample preparation for PI staining and flow cytometry measurements are more time consuming, viability determination by flow cytometry proved to be more sensitive and reliable for $\mathrm{SiO}_{2}$ NP. It has been demonstrated that when PI staining is performed in plate-based assays, it can bind to NPs and be transported inside the cells resulting in falsenegative results [11]. However in case of flow cytometry PI staining is performed after media containing NP is removed, the cells are harvested from the plate and washed several times, all of which reduces the possibility of false-negative results through that particular mechanism. However, when preparing the samples for flow cytometry assay, especially in the case of adherent cells, cells should be carefully harvested, making sure that certain subpopulations are not lost or damaged during sample preparation (due to centrifugation or incomplete trypsin digestion), and cells are thoroughly processed to single-cell suspension. These considerations are applicable for Coulter counter assays as well. Therefore in the present study adherent and cell suspension cultures were used for flow cytometry and Coulter counter measurements.

Once NPs are phagocytosed, they can change cells' granularity. This feature was captured in flow cytometry analysis where $\mathrm{SiO}_{2}$ NPs-treated RAW 264.7 cells showed changes in granularity. Therefore, modification in SSC can serve as a good indicator of NP incorporation (Figure 4(a)) or cell activation (as seen in case of LPS treatment; Figure 4(a)). Cell populations exhibiting changes in SSC can be identified and selectively sorted (using a cell sorter) if highly purified cell populations are required. 
Even in cases when NP interference with plate-based or other absorbance or fluorescent-based assays is not detected, it is highly recommended that NPs are well characterized, controls (no cell controls, pre- and postspike, positive controls) are included, and results are confirmed by a battery of assays and techniques. By using a combination of plate-base assays, flow cytometry, Coulter counter assays and microscopy analysis we showed that concentrations of $0.001 \mathrm{~g} / \mathrm{L}-0.01 \mathrm{~g} / \mathrm{L}$ colloidal $\mathrm{SiO}_{2} \mathrm{NPs}(7 \mathrm{~nm})$ do not cause cytotoxicity in RAW 264.7 cells but determine an increase in granularity and cell size and decrease in cell number at $24 \mathrm{~h}$.

We conclude that (1) although we could not detect common causes of $\mathrm{SiO}_{2}$ NPs interference with plate-based assays at low $\mathrm{SiO}_{2} \mathrm{NP}$ concentrations, plate-based assays and flow cytometry assays do not correlate; (2) flow cytometry staining was more sensitive in detecting decreased cell viability; (3) Coulter counter assay detected decreased proliferation and changes in cell size; (4) a panel of different techniques is required in order to determine and validate in vitro studies.

\section{Disclosure}

The findings and conclusions in this paper have not been formally disseminated by the Food and Drug Administration and should not be construed to represent any agency determination or policy. The mention of commercial products, their sources, or their use in connection with material reported herein is not to be construed as either an actual or implied endorsement of such products by the Department of Health and Human Services or by the National Institute of Standards and Technology.

\section{Conflict of Interests}

The authors do not have any conflict of interests.

\section{Acknowledgments}

The authors acknowledge the Office of Science and Engineering Laboratories, FDA, for the use of their TEM and TGA. This project was supported in part by an appointment to the Research Participation Program at the Center for Drug Evaluation and Research administered by the Oak Ridge Institute for Science and Education through an interagency agreement between the U.S. Department of Energy and the U.S. Food and Drug Administration.

\section{References}

[1] M. Chidambaram, R. Manavalan, and K. Kathiresan, "Nanotherapeutics to overcome conventional cancer chemotherapy limitations," Journal of Pharmacy and Pharmaceutical Sciences, vol. 14, no. 1, pp. 67-77, 2011.

[2] R. Sinha, G. J. Kim, S. Nie, and D. M. Shin, "Nanotechnology in cancer therapeutics: bioconjugated nanoparticles for drug delivery," Molecular Cancer Therapeutics, vol. 5, no. 8, pp. 1909-1917, 2006.
[3] E. Blanco, A. Hsiao, A. P. Mann, M. G. Landry, F. MericBernstam, and M. Ferrari, "Nanomedicine in cancer therapy: innovative trends and prospects," Cancer Science, vol. 102, no. 7, pp. 1247-1252, 2011.

[4] W. L. Monsky, D. S. Vien, and D. P. Link, "Nanotechnology development and utilization: a primer for diagnostic and interventional radiologists," Radiographics, vol. 31, no. 5, pp. 1449-1462, 2011.

[5] S. Katteboinaa, V. S. R. Chandrasekhar P, and S. Balaji, "Drug nanocrystals: a novel formulation approach for poorly soluble drugs," International Journal of PharmTech Research, vol. 1, no. 3, pp. 682-694, 2009.

[6] J. M. McKim, "Building a tiered approach to in vitro predictive toxicity screening: a focus on assays with in vivo relevance," Combinatorial Chemistry and High Throughput Screening, vol. 13, no. 2, pp. 188-206, 2010.

[7] R. Damoiseaux, S. George, M. Li et al., "No time to losehigh throughput screening to assess nanomaterial safety," Nanoscale, vol. 3, no. 4, pp. 1345-1360, 2011.

[8] S. Y. Shaw, E. C. Westly, M. J. Pittet, A. Subramanian, S. L. Schreiber, and R. Weissleder, "Perturbational profiling of nanomaterial biologic activity," Proceedings of the National Academy of Sciences of the United States of America, vol. 105, no. 21, pp. 7387-7392, 2008.

[9] A. Kroll, C. Dierker, C. Rommel et al., "Cytotoxicity screening of 23 engineered nanomaterials using a test matrix of ten cell lines and three different assays," Particle and Fibre Toxicology, vol. 23, article 9, 2011.

[10] S. George, T. Xia, R. Rallo et al., "Use of a high-throughput screening approach coupled with in vivo zebrafish embryo screening to develop hazard ranking for engineered nanomaterials," ACS Nano, vol. 5, no. 3, pp. 1805-1817, 2011.

[11] A. M. Keene, R. J. Allaway, N. Sadrieh, and K. M. Tyner, "Gold nanoparticle trafficking of typically excluded compounds across the cell membrane in JB6 Cl 41-5a cells causes assay interference," Nanotoxicology, vol. 5, no. 4, pp. 469-478, 2011.

[12] B. Kong, J. H. Seog, L. M. Graham, and S. B. Lee, "Experimental considerations on the cytotoxicity of nanoparticles," Nanomedicine, vol. 6, no. 5, pp. 929-941, 2011.

[13] G. J. Oostingh, E. Casals, P. Italiani et al., "Problems and challenges in the development and validation of human cell-based assays to determine nanoparticle-induced immunomodulatory effects," Particle and Fibre Toxicology, vol. 8, article 8, 2011.

[14] D. B. Warheit, C. M. Sayes, and K. L. Reed, "Nanoscale and fine zinc oxide particles: can in vitro assays accurately forecast lung hazards following inhalation exposures?" Environmental Science and Technology, vol. 43, no. 20, pp. 7939-7945, 2009.

[15] C. Hoskins, L. Wang, W. P. Cheng, and A. Cuschieri, "Dilemmas in the reliable estimation of the in-vitro cell viability in magnetic nanoparticle engineering: which tests and what protocols?" Nanoscale Research Letters, vol. 7, Article ID 77, pp. 1-22, 2012.

[16] W. Wohlleben, S. N. Kolle, L.-C. Hasenkamp et al., "Artifacts by marker enzyme adsorption on nanomaterials in cytotoxicity assays with tissue cultures," Journal of Physics, vol. 304, no. 1, Article ID 012061, 2011.

[17] A. Kroll, M. H. Pillukat, D. Hahn, and J. Schnekenburger, "Current in vitro methods in nanoparticle risk assessment: limitations and challenges," European Journal of Pharmaceutics and Biopharmaceutics, vol. 72, no. 2, pp. 370-377, 2009.

[18] M. S. K. Zaqout, T. Sumizawa, H. Igisu, D. Wilson, T. Myojo, and S. Ueno, "Binding of titanium dioxide nanoparticles to 
lactate dehydrogenase," Environmental Health and Preventive Medicine, vol. 17, no. 4, pp. 341-345, 2012.

[19] X. Han, R. Gelein, N. Corson et al., "Validation of an LDH assay for assessing nanoparticle toxicity," Toxicology, vol. 287, no. 1-3, pp. 99-104, 2011.

[20] A. Casey, E. Herzog, M. Davoren, F. M. Lyng, H. J. Byrne, and G. Chambers, "Spectroscopic analysis confirms the interactions between single walled carbon nanotubes and various dyes commonly used to assess cytotoxicity," Carbon, vol. 45, no. 7, pp. 1425-1432, 2007.

[21] A. Dhawan and V. Sharma, "Toxicity assessment of nanomaterials: methods and challenges," Analytical and Bioanalytical Chemistry, vol. 398, no. 2, pp. 589-605, 2010.

[22] B. Wahl, N. Daum, H. L. Ohrem, and C. M. Lehr, "Novel luminescence assay offers new possibilities for the risk assessment of silica nanoparticles," Nanotoxicology, vol. 2, no. 4, pp. 243 251, 2008.

[23] S. Santra, "Fluorescent silica nanoparticles for cancer imaging," Methods in Molecular Biology, vol. 624, pp. 151-162, 2010.

[24] P. Couleaud, D. Bechet, R. Vanderesse et al., "Functionalized silica-based nanoparticles for photodynamic therapy," Nanomedicine, vol. 6, no. 6, pp. 995-1009, 2011.

[25] A. Burns, H. Ow, and U. Wiesner, "Fluorescent core-shell silica nanoparticles: towards "lab on a particle" architectures for nanobiotechnology," Chemical Society Reviews, vol. 35, no. 11, pp. 1028-1042, 2006.

[26] J. Lu, M. Liong, Z. Li, J. I. Zink, and F. Tamanoi, "Biocompatibility, biodistribution, and drug-delivery efficiency of mesoporous silica nanoparticles for cancer therapy in animals," Small, vol. 6, no. 16, pp. 1794-1805, 2010.

[27] C. Hom, J. Lu, and F. Tamanoi, "Silica nanoparticles as a delivery system for nucleic acid-based reagents," Journal of Materials Chemistry, vol. 19, no. 35, pp. 6308-6316, 2009.

[28] C. Hom, J. Lu, M. Liong et al., "Mesoporous silica nanoparticles facilitate delivery of siRNA to shutdown signaling pathways in mammalian cells," Small, vol. 6, no. 11, pp. 1185-1190, 2010.

[29] I. I. Slowing, J. L. Vivero-Escoto, C. W. Wu, and V. S. Y. Lin, "Mesoporous silica nanoparticles as controlled release drug delivery and gene transfection carriers," Advanced Drug Delivery Reviews, vol. 60, no. 11, pp. 1278-1288, 2008.

[30] J. M. Rosenholm, V. Mamaeva, C. Sahlgren, and M. Lindén, "Nanoparticles in targeted cancer therapy: mesoporous silica nanoparticles entering preclinical development stage," Nanomedicine, vol. 7, no. 1, pp. 111-120, 2012.

[31] D. Napierska, L. C. J. Thomassen, D. Lison, J. A. Martens, and P. H. Hoet, "The nanosilica hazard: another variable entity," Particle and Fibre Toxicology, vol. 7, article 39, 2010.

[32] T. Aubert, F. Grasset, S. Mornet et al., "Functional silica nanoparticles synthesized by water-in-oil microemulsion processes," Journal of Colloid and Interface Science, vol. 341, no. 2, pp. 201-208, 2010.

[33] Y. L. Zhao, Z. Li, S. Kabehie, Y. Y. Botros, J. F. Stoddart, and J. I. Zink, "pH-operated nanopistons on the surfaces of mesoporous silica nanoparticles," Journal of the American Chemical Society, vol. 132, no. 37, pp. 13016-13025, 2010.

[34] C. Uboldi, G. Giudetti, F. Broggi, D. Gilliland, J. Ponti, and F. Rossi, "Amorphous silica nanoparticles do not induce cytotoxicity, cell transformation or genotoxicity in Balb/3T3 mouse fibroblasts," Mutation Research, vol. 745, no. 1-2, pp. 11-20, 2012.

[35] B. M. Mohamed, N. K. Verma, A. Prina-Mello et al., "Activation of stress-related signalling pathway in human cells upon
$\mathrm{SiO}_{2}$ nanoparticles exposure as an early indicator of cytotoxicity," Journal of Nanobiotechnology, vol. 9, article 29, 2011.

[36] M. J. Akhtar, M. Ahamed, S. Kumar et al., "Nanotoxicity of pure silica mediated through oxidant generation rather than glutathione depletion in human lung epithelial cells," Toxicology, vol. 276, no. 2, pp. 95-102, 2010.

[37] H. J. Eom and J. Choi, " $\mathrm{SiO}_{2}$ nanoparticles induced cytotoxicity by oxidative stress in human bronchial epithelial cell, beas-2B," Environmental Health and Toxicology, vol. 26, article e2011013, 2011.

[38] T. Yu, A. Malugin, and H. Ghandehari, "Impact of silica nanoparticle design on cellular toxicity and hemolytic activity," ACS Nano, vol. 5, no. 7, pp. 5717-5728, 2011.

[39] M. Fisichella, H. Dabboue, S. Bhattacharyya et al., "Mesoporous silica nanoparticles enhance MTT formazan exocytosis in HeLa cells and astrocytes," Toxicology in Vitro, vol. 23, no. 4, pp. 697-703, 2009.

[40] D. H. Tsai, R. A. Zangmeister, L. F. Pease, M. J. Tarlov, and M. R. Zachariah, "Gas-phase ion-mobility characterization of SAM-functionalized Au nanoparticles," Langmuir, vol. 24, no. 16, pp. 8483-8490, 2008.

[41] D. H. Tsai, L. F. Pease, R. A. Zangmeister, M. J. Tarlov, and M. R. Zachariah, "Aggregation kinetics of colloidal particles measured by gas-phase differential mobility analysis," Langmuir, vol. 25, no. 1, pp. 140-146, 2009.

[42] N. A. Monteiro-Riviere, A. O. Inman, and L. W. Zhang, "Limitations and relative utility of screening assays to assess engineered nanoparticle toxicity in a human cell line," Toxicology and Applied Pharmacology, vol. 234, no. 2, pp. 222-235, 2009.

[43] M. C. Pagliacci, F. Spinozzi, G. Migliorati et al., "Genistein inhibits tumour cell growth in vitro but enhances mitochondrial reduction of tetrazolium salts: a further pitfall in the use of the MTT assay for evaluating cell growth and survival," European Journal of Cancer A, vol. 29, no. 11, pp. 1573-1577, 1993.

[44] J. T. Sims and R. Plattner, "MTT assays cannot be utilized to study the effects of STI571/Gleevec on the viability of solid tumor cell lines," Cancer Chemotherapy and Pharmacology, vol. 64, no. 3, pp. 629-633, 2009. 

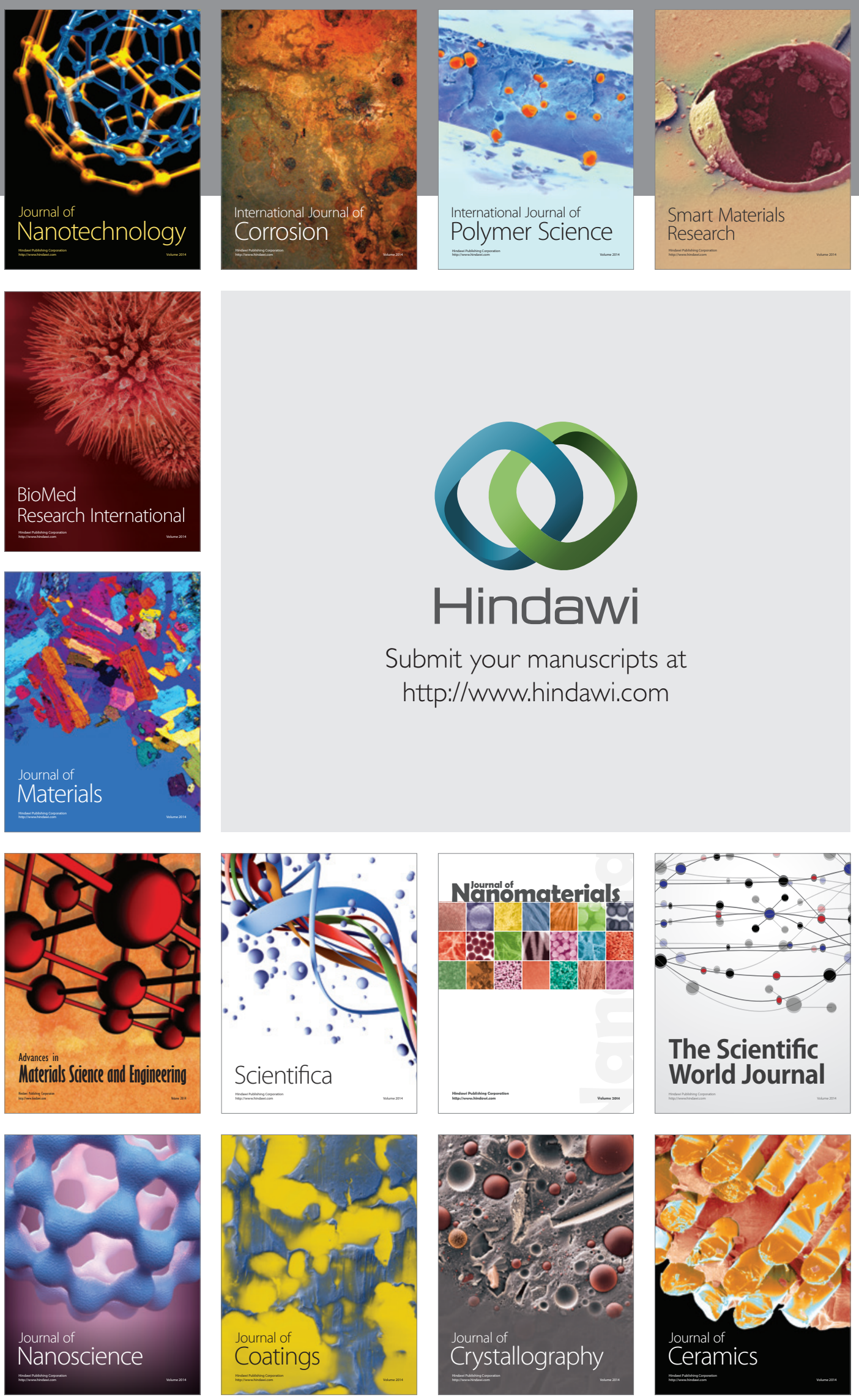

The Scientific World Journal

Submit your manuscripts at

http://www.hindawi.com

\section{World Journal}

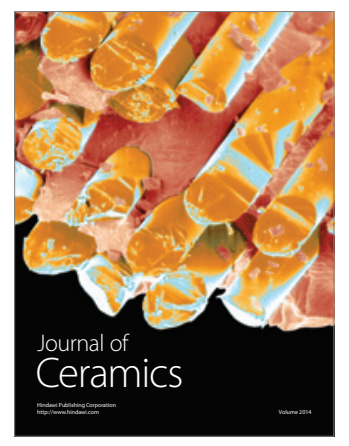

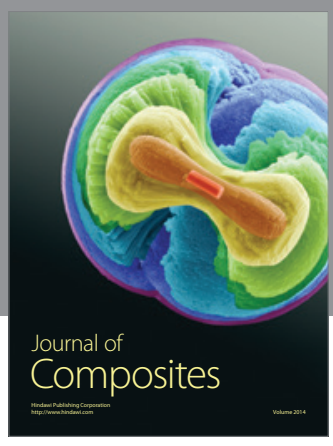
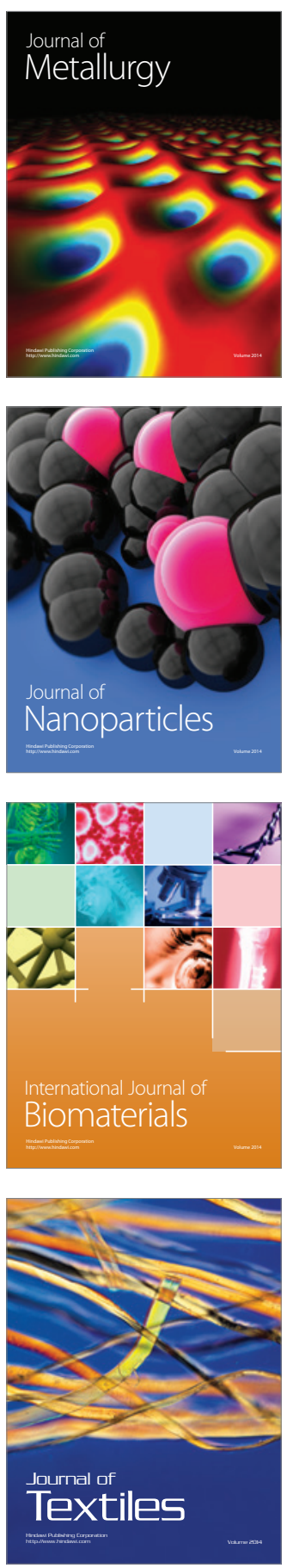